\title{
РЕЗУЛЬТАТЫ АПРОБИРОВАНИЯ МЕТОДИКИ ОЦЕНКИ КОМФОРТНОСТИ ЖИЗНЕДЕЯТЕЛЬНОСТИ НА ПРИМЕРЕ АЙХАЛЬСКОГО ГОРНОДОБЫВАЮЩЕГО КОМПЛЕКСА РАЙОНА КРИОЗОНЫ (ЯКУТИЯ)
}

\author{
М. А. Хованская, И. И. Косинова, М. Г. Воробьева \\ Воронежский государственный университет \\ Поступила в редакцию 26 февраля 2018 г.
}

\begin{abstract}
Аннотация: представлены результаты апробирования авторской методики оценки комфортности жизнедеятельности горнодобывающих районов, расположенных в зоне распространения вечномёрзльх пород, на примере территории Айхальского горно-промышленного комплекса (ГПК), как типового объекта геолого-разведочной и горной деятельности криозоны. Выявлено, что максимальный дискомфорт создают добычные, перерабатывающие и разведочные работы. Зона с весьма некомфортными условиями жизнедеятельности приурочена к местоположению алмазосодержащих трубок Айхал, Сытыкан и Юбилейная. В районе проведения разведочных работ формируются зоны весьма некомфортных и некомфортных условий жизнедеятельности. Минимальное воздействие на все компоненты природной среды оказывают поисковые работы, в районе проведения которых фиксируются условно комфортные условия жизнедеятельности. Территории, на которых отсутствуют какие-либо виды техногенного воздействия на природную геоэкологическую среду (ГЭС), были оценены как комфортные.

Ключевые слова: горнодобывающая деятельность; вечномёрзлье породы; воздействие геологоразведочной и горной деятельности; комфортность жизнедеятельности; преобразование компонентов природной среды; техногенез.
\end{abstract}

\section{RESULTS PROBING THE METHOD OF ASSESSING THE COMFORT OF LIFE ON THE EXAMPLE OF THE AYKHAL MINING PROCESSING COMPLEX IN THE CRIOREGION DISTRICT (YAKUTIA)}

\begin{abstract}
: there are the results of testing the author's methodology for assessing the comfort of the mining areas of life, located in the zone of permafrost rocks, by the example of the mining complex of the territory Aikhal as a model object exploration and mining activities in the area of dissemination of permafrost. Revealed that the maximum discomfort create mining and processing, as well as exploration. Area with very uncomfortable conditions of life dedicated to the location of diamond pipes Aikhal, Sytykan and Jubilee. In the area of exploration zones are formed very uncomfortable and uncomfortable living conditions. Minimal impact on all components of the environment have exploratory work in the area of which are fixed arbitrarily comfortable living conditions. Areas in which there are no kinds of anthropogenic impact on the natural geo-ecological components of the environment, were evaluated as comfortable.

Keywords: mining activities, permafrost rocks, the impact of exploration and mining activities, comfort of life, the transformation of environmental components, technogenesis.
\end{abstract}

На территории России горнодобывающая деятельность, как правило, расположена в уникальных природных условиях, в том числе в районах вечной мерзлоты. Комфортность жизнедеятельности данных районов зависит от природных факторов. Например, климатические факторы влияют на степень пригодности и комфортности существования и жизнедеятельности человека. Состав горных пород также влияет на комфортность. Это выражается в уникальных геохимических воздействиях горных пород на живые организмы, обусловленных содержанием в них таких элементов, как, например, тяжёлые металлы, которые оказывают весомое влияние на состояние здоровья и комфортность жизни человека. Данный факт подтверждается наличием эндемичных условий существования экосистем. Кроме этого на степень комфорт- 
ности жизнедеятельности влияют и техногенные факторы, выражающиеся в виде загрязнения компонентов природной среды в результате деятельности человека.

Типичным примером горнодобывающих районов вечной мерзлоты является Айхальский горнопромышленный комплекс (ГПК), расположенный в республике Саха-Якутия. В данном районе с середины 20 века ведется алмазодобыча открытым карьерным способом на трех месторождениях, среди которых трубки «Айхал», «Сытыкан» и «Юбилейная». Полное вскрытие мерзлой толщи приводит к дестабилизации гидро, педо-, лито-, атмо- и биосфер района $[4,5]$.

В данной статье авторы представили результаты применения разработанной методики оценки комфортности жизнедеятельности на примере горнодобывающего района поселка Айхал, который расположен в криозоне [6, 7]. В современном понимании комфортность представляет собой состояние учёта удобств, обеспечивающих положительные психологические и физиологические ощущения человека в процессе трудовой деятельности [5]. Среди основных направлений обеспечения комфортности ведущими являются мероприятия по созданию искусственной инфраструктуры, удовлетворяющей требованиям человека в процессе жизнедеятельности. Основное противоречие состоит в ограниченности существующего подхода для районов горнодобывающей деятельности, расположенных в зоне вечной мерзлоты. Для них комфортность формируется также в зависимости от загрязнения природной среды. В этой связи под комфортностью следует понимать комплекс условий среды жизнедеятельности, включающей природные геоэкологические факторы и степень загрязнения компонентов геоэкологической системы (ГЭС).

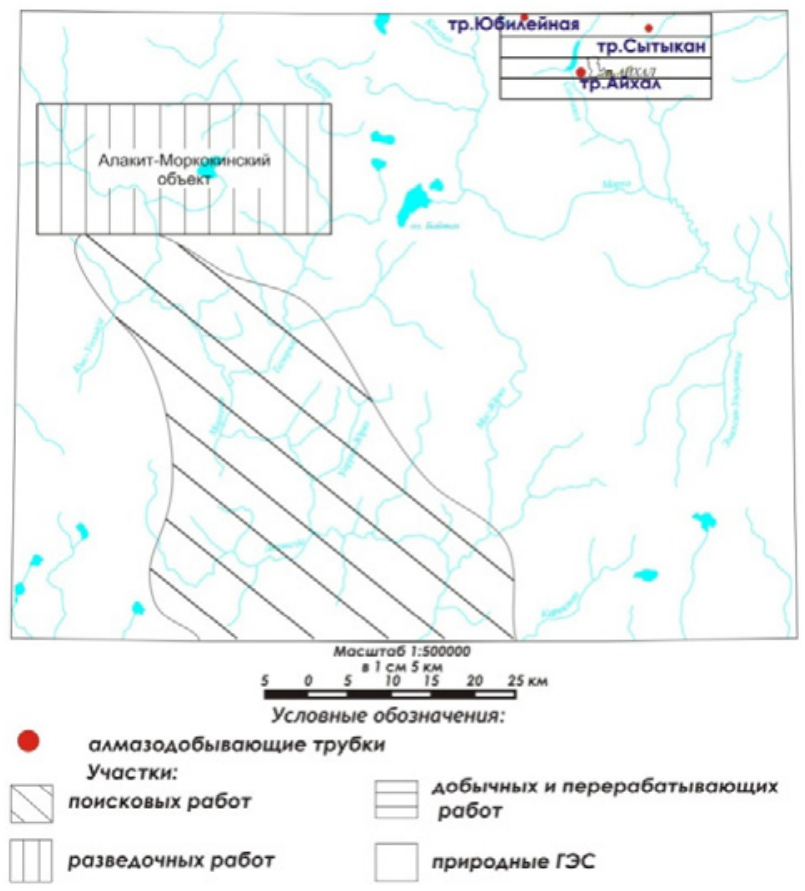

Puc. 1. Схема освоения территории Айхальского горнопромышленного комплекса.
Комфортность определялась путём оценки трансформации компонентов природной среды [3]. Были изучены снеговые, почвенные и донные отложения, поверхностные воды и элементы растительности. Геологическая деятельность, ведущаяся в Айхальском ГПК, представлена следующими видами работ: геологоразведочными, включающими в себя поисковые и разведочные, а также горными, среди которых добычные и перерабатывающие (рис.1).

Согласно методике оценки комфортности жизнедеятельности в горнодобывающих районах в местах распространения вечномерзлых пород [7] в период с 2005 по 2010 гг в Айхальском горнопромышленном комплексе изучался уровень воздействия отдельных видов геологоразведочной и горной деятельности на компоненты ГЭС $(S)$, на основании чего производилась оценка комфортности жизнедеятельности.

Для формирования комплексной геоэкологической оценки был проведен анализ каждого компонента природной среды:

А) Снеговые отложения. По результатам исследований природной среды на изучаемой территории с помощью анализа снеговых отложений было выявлено, что максимальные превышения фоновых значений фиксируются по $\mathrm{Zn}, \mathrm{Pb}, \mathrm{Cu}$ и $\mathrm{Ni}$ [2]. Их высокие содержания в талой воде на территории Айхальского ГПК отмечены в местах проведения геологоразведочных, добычных и перерабатывающих работ и объясняются содержанием растворимой пыли карбонатнокимберлитовых пород, поступающей в атмосферу с буровзрывным облаком.

Данные виды работ формируют чрезвычайно опасное состояние снеговых отложений, что подтверждается превышениями фоновых концентраций загрязняющих веществ более чем в 12,5 раз. В районе ведения поисковых работ (р. Моркока) экологическое состояние снеговых отложений оценивается как умеренно опасное (Рис. 2).

Б) Почвенные отложения. При анализе компонентов, загрязняющих почвенные отложения, выявлены повышенные содержания тяжелых металлов, таких как $\mathrm{Zn}, \mathrm{Pb}, \mathrm{Cu}$ и $\mathrm{Ni}$. Это обусловлено как природными, так и техногенными факторами. К природным факторам можно отнести наличие на изучаемой территории кимберлит-вмещающих пород. Они характеризуются повышенными содержаниями вышеперечисленных элементов и имеют тесную связь с почвенными отложениями [4].

Техногенные факторы представлены проводимыми на территории Айхальского ГПК работами, связанными с разработкой алмазов. Так поисковые работы формируют зону умеренно опасного экологического состояния почвенных отложений, занимающую около 60 \% изучаемой территории (рис. 3). Зона опасного экологического состояния почв расположена на севере района и приурочена к местам ведения разведочных, добычных и перерабатывающих работ. Их негативное воздействие обусловлено буровой, карьерной и буровзрывной деятельностью, при которой 
цинк, свинец, медь и никель вместе с пылью и поднятыми на поверхность породами поступают на прилегающие территории.

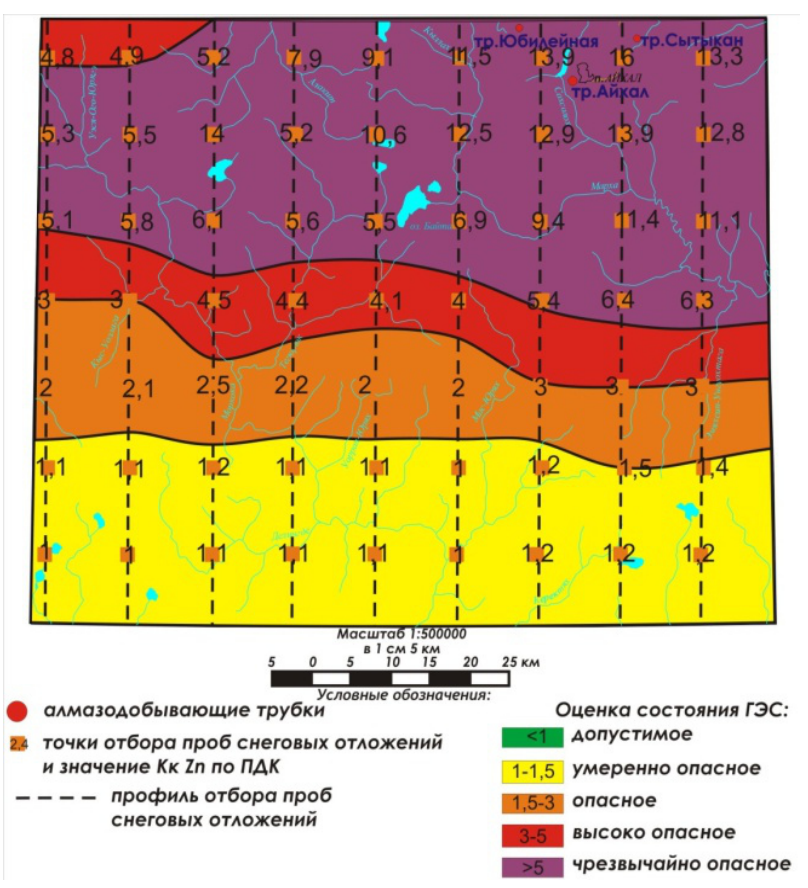

Puc. 2. Карта эколого-геохимической оценки снеговых отложений.

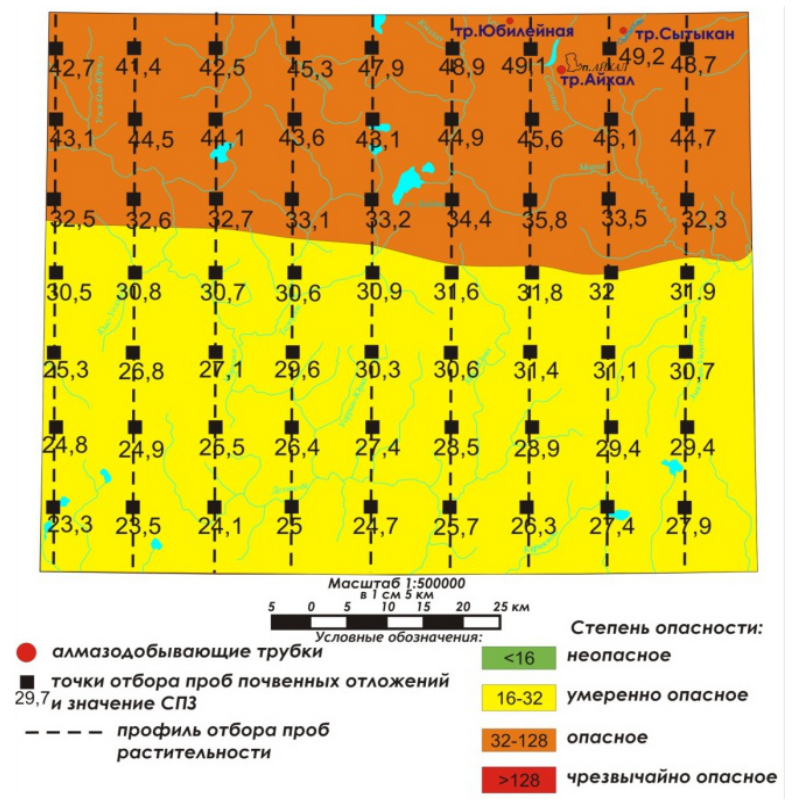

Puc. 3. Карта эколого-геохимической оценки почвенных отложений.

В) Поверхностные воды. Формирование химического состава поверхностных вод обусловлено существующими природно-техногенными аномалиями. Так большая часть рек района протекает по карбонатным отложениям и характеризуется допустимой оценкой экологического состояния (р. Делингде, p. Мас-Юрях, р. Тегюрюк и т.д.).
Максимальные концентрации цинка в водах $\mathrm{p}$. Моркока отмечаются на участке реки, где она размывает породы кристаллического фундамента. Это приводит к формированию умеренно опасного экологического состояния ГЭС.

Негативное воздействие геологоразведочных работ, ведущихся на Алакит-Моркокинском объекте, подтверждается отклонением от природных концентраций элементов-загрязнителей. Большая часть повышенных содержаний свинца территориально соответствует расположению участка, где бурение скважин производилось по наиболее густой сети. Так в районе оз. Ого-Кюэль фиксируется зона умеренно опасного экологического состояния поверхностных вод.

Влияние добычных и перерабатывающих работ на поверхностные воды выражается в повышенных содержания в них тяжелых металлов, источниками поступления которых являются отвалы алмазоносной отработки. При промывке данных отложений в поверхностные воды в растворимой форме поступают $\mathrm{Zn}, \mathrm{Li}, \mathrm{Pb}, \mathrm{Cu}$, вымываемые из пород отработки [2].

В техногенно образованном Сохсоолохском водохранилище, в котором ведется отстаивание горных пород, фиксируется высоко опасная оценка состояния поверхностных вод. Техногенное заражение ручья Сохсоолох фиксируется и в 8 км ниже трубки Айхал.

Г) Донные отложения. Основные результаты, полученные при анализе степени загрязнения донных отложений на территории Айхальского ГПК по величине суммарного показателя загрязнения (СПЗ), представлены в виде карты их экологического состояния. Следует также отметить комплексное влияние на состав донных отложений природных и техногенных факторов. Так природные обусловлены наличием зон тектонических нарушений и проявлены в виде содержаний хрома, кобальта, иттрия, ниобия, скандия. Их аномальные концентрации приурочены к рекам, дренирующим породы кристаллического фундамента. Подобные природные аномалии фиксируются в долинах рек Моркока, Алакит.

Повышенное содержание свинца приурочено к местам проведения геологоразведочных работ на Алакит-Моркокинском объекте. Свинец имеет преимущественно техногенное происхождение. Так донные отложения р. Уэся-Юрягэ, приустьевая часть руч. Блудливый, оз. Ого-Кюэль и небольшой участок долины р. Моркока характеризуются опасным экологическим состоянием. Интенсивное проведение буровых работ с выемкой глубинных пород на поверхность также оказывают интенсивное воздействие на формирование химического состава поверхностных вод изучаемых водотоков.

В северо-восточной части изучаемой территории донные отложения характеризуются опасным и чрезвычайно опасным экологическим состоянием, что подтверждает интенсивное воздействие добычных и перерабатывающих работ. Пики загрязнения приурочены к местоположению алмазосодержащих трубок 
Айхал, Сытыкан и Юбилейная. Основными загрязняющими элементами являются $\mathrm{Zn}, \mathrm{Pb}, \mathrm{Cu}, \mathrm{Ni}, \mathrm{Cr}$, и $\mathrm{Co}$, которые поступают в донные осадки при буровзрывных работах [2].

Д) Элементы растительности (лишайники). В результате оценки экологического состояния элементов растительности было выявлено, что повышенные содержания таких элементов как $\mathrm{Cu}, \mathrm{Cr}, \mathrm{Zn}, \mathrm{Ni}, \mathrm{Pb}$ приурочены к местам проведения геологоразведочных, добычных и перерабатывающих работ.

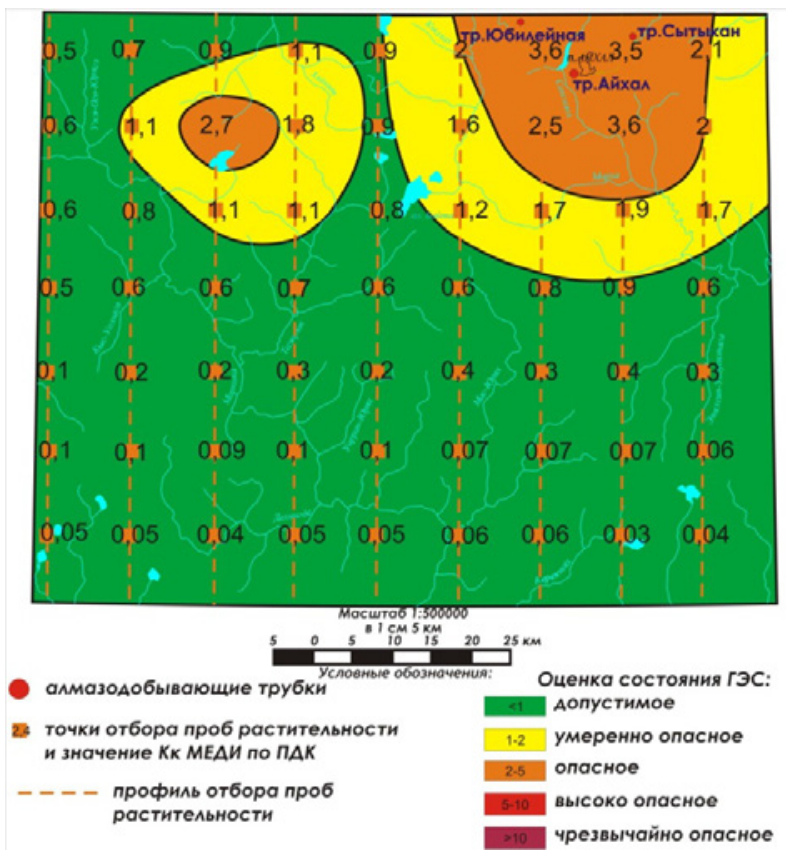

Puc. 4. Карта эколого-геохимической оценки растительности по содержанию меди.

Они поступают в природные сферы при буровзрывных работах, выбросах выхлопных газов от тягачей и тяжёлой техники, формировании отвалов при обогащении алмазов. На фоне зон допустимого и умеренно опасного уровня загрязнения выделена зона опасного уровня загрязнения (по меди), совпадающая с местонахождением алмазных трубок и ведением геологоразведочных работ на Алакит-Моркокинском объекте (рис. 4).

Оценка комфортности жизнедеятельности территории Айхальского ГПК включала в себя аддитивный анализ геохимических и механических факторов преобразования компонентов природной среды, наиболее характерных для горнодобывающих районов распространения вечномерзлых пород.

Сравнение эколого-геохимических критериев абиотических и биотических компонентов природной среды производилось путём унификации оценочных показателей эколого-геохимических аномалий с помощью введения геохимического балла [7].

Почвенные и донные отложения являются депонирующими средами, накапливающими многолетние загрязнения. Оценка состояния данных сред производилась по значениям суммарных показателей загрязнения (СПЗ). Растительность, снеговые отложения и поверхностные воды можно оценить как ограниченно депонирующими, т.к. они накапливают загрязнение в течение определенного периода года.

Переход от значения СПЗ, которое не является аддитивным для различных сред (нельзя складывать СПЗ по почвенным, донным отложениям и т.д.) к аддитивным геохимическим баллам, осуществляется через логарифмирование величины СПЗ, определяющей число состояний абиотической среды. Логарифм числа состояний техногенно нагруженной геоэкологической системы назовем геохимическим баллом и обозначим его через $\mathrm{N}$.

Формулы перехода, приведенные в таблице 1, позволяют привести разнородные измерения к единой геохимической шкале [7].

Оценка комфортности жизнедеятельности горнодобывающих районов в местах распространения вечномерзлых пород проводится на основе типизации эколого-геохимических аномалий и учета степени механической деградации почв.

Таблица 1

Система перехода геохимических показателей к бальной шкале

\begin{tabular}{|c|c|c|c|c|c|c|c|c|}
\hline \multirow{2}{*}{$\begin{array}{c}\text { № } \\
\text { П/П } \\
\end{array}$} & \multirow{2}{*}{$\begin{array}{c}\text { Критерии } \\
\text { оценки }\end{array}$} & \multicolumn{6}{|c|}{ Геохимический балл N } & \multirow{2}{*}{$\begin{array}{l}\text { Формула } \\
\text { перехода }\end{array}$} \\
\hline & & $\mathrm{N}=0$ & $0<\mathrm{N}<1$ & $1 \leq \mathrm{N}<2$ & $2 \leq \mathrm{N}<3$ & $3 \leq \mathrm{N}<4$ & $\mathrm{~N}=4$ & \\
\hline 1 & $\begin{array}{c}\text { Почвенные } \\
\text { отложения (СП3) }\end{array}$ & $<8$ & $8-16$ & $16-32$ & $32-64$ & $64-128$ & $>128$ & $\left(\log _{2} \mathrm{C \Pi}\right)-3$ \\
\hline 2 & $\begin{array}{c}\text { Растительность } \\
\text { (ПДК) }\end{array}$ & $<1$ & $1-2$ & $2-4$ & $4-8$ & $8-16$ & $>16$ & $\log _{2} \mathrm{~K} \kappa$ \\
\hline 3 & $\begin{array}{c}\text { Снеговые отло- } \\
\text { жения (фоновые } \\
\text { содержания) } \\
\text { 1,2-го классов } \\
\text { опасности }\end{array}$ & $<1$ & $1-2$ & $2-4$ & $4-8$ & $8-16$ & $>16$ & $\log _{2} K \phi$ \\
\hline 4 & $\begin{array}{c}\text { Поверхностные } \\
\text { вод (ПДК) } \\
\text { 1, 2-го классов } \\
\text { опасности } \\
\end{array}$ & $<1$ & $1-2$ & $2-4$ & $4-8$ & $8-16$ & $>16$ & $\log _{2} \mathrm{K \kappa}$ \\
\hline 5 & $\begin{array}{c}\text { Донные } \\
\text { отложения (СП3) } \\
\end{array}$ & $<8$ & $8-16$ & $16-32$ & $32-64$ & $64-128$ & $>128$ & $\left(\log _{2} \mathrm{C} \Pi 3\right)-3$ \\
\hline
\end{tabular}


При оценке степени деградации почвенного покрова использовался показатель $M$, измеряемый в процентах, который представляет собой уменьшение мощности почвенного профиля от исходного. Под исходным понимается состояние недеградированных аналогов (нулевой уровень деградации) [8].

Степень деградации почв (ДП) приводится в соответствии с таблицей 2 на основании методики определения размеров ущерба от деградации почв и земель.

Таблица 2

Определение степени деградаичии почв ДП

\begin{tabular}{|c|c|c|c|c|c|}
\hline \multirow{2}{*}{ Показатель $M$} & \multicolumn{5}{|c|}{ Степень деградации (баллы) } \\
\cline { 2 - 6 } & 0 & 1 & 2 & 3 & 4 \\
\hline $\begin{array}{c}\text { Уменьшение мощ- } \\
\text { ности почвенного } \\
\text { профиля от исход- } \\
\text { ного, проценты }\end{array}$ & $<3$ & $3-25$ & $26-50$ & $51-75$ & $>75$ \\
\hline
\end{tabular}

В результате, выделяется 5 степеней деградации почв (ДП) (Таблица 3).

Таблица 3

Оценка степени деградаџии почвенного покрова

\begin{tabular}{|c|c|}
\hline Балл & Степень деградации почв \\
\hline 0 & недеградированные (ненарушенные) \\
\hline 1 & слабодеградированные \\
\hline 2 & среднедеградированные \\
\hline 3 & сильнодеградированные \\
\hline 4 & очень сильнодеградированные (разрушенные) \\
\hline
\end{tabular}

Уровень воздействия различных видов геологоразведочной и горной деятельности на компоненты природной среды $(S)$ в точке $i$ оценивается по формуле 1:

$$
S_{i}=Д_{i}+\sum_{j=1}^{5} \lambda_{j} N_{i} \quad \forall_{i}=\overline{1, n}(1)
$$

где $S_{i}$ - уровень воздействия различных видов работ в $i$-той точке наблюдения, ДП - степень деградации почв в $i$-той точки, $N_{j i}-$ геохимический балл $j$-той среды (снеговые, почвенные, донные отложения, поверхностные воды, растительность) для $i$-той точки, $\lambda_{j}$
- весовой коэффициент $j$-той среды, $\mathrm{n}$ - количество исследуемых точек пробоотбора.

Оценка комфортности жизнедеятельности. Градации для границ экологических рангов будут определяться выражением:

$$
K_{i}=2^{q} \sum_{j=1}^{5} \lambda_{j}
$$

где $K_{i}-i$-тая градация комфортности жизнедеятельности; $q=0,1,2,3$ для границ соответствующих экологических рангов; $\lambda_{j}-$ весовой коэффициент $j$-той среды.

Таким образом, в каждой точке наблюдения оценивается уровень воздействия различных видов геологоразведочной и горной деятельности $S$ на компоненты природной среды, соответствующий уровню комфортности жизнедеятельности, которая ранжируется по таблице 4.

Таблица 4

Оценка комфортности жизнедеятельности

\begin{tabular}{|c|c|c|}
\hline K & Градация & Условия жизнедеятельности \\
\hline $\mathrm{S} \leq 3,4$ & I & Комфортные \\
\hline $3,4<\mathrm{S} \leq 6,8$ & II & Условно комфортные \\
\hline $6,8<\mathrm{S} \leq 13,6$ & III & Некомфортные \\
\hline $13,6<\mathrm{S} \leq 27,2$ & IV & Весьма некомфортные \\
\hline $\mathrm{S}>27,2$ & $\mathrm{~V}$ & Чрезвычайно некомфортные \\
\hline
\end{tabular}

Анализируя итоги проведенных работ (табл. 5, рис. 5), можно сделать вывод, что территории, характеризующиеся весьма некомфортными условиями жизнедеятельности, приурочены к местам проведения добычных и перерабатывающих работ. Максимальную степень воздействия добычные работы оказывают на снеговые отложения, что подтверждается их чрезвычайно опасным экологическим состоянием.

Загрязняющие элементы, поступающие при разработке алмазов, переносятся на несколько десятков километров (до 40 км) и приводят к изменениям химического состава всех компонентов природной среды, формируя опасные, высоко опасные и чрезвычайно опасные уровни загрязнения. Зона, характери зующаяся весьма некомфортными условиями

Таблица 5

\begin{tabular}{|c|c|c|c|c|c|c|c|c|c|c|}
\hline \multirow{2}{*}{$\begin{array}{c}\text { № } \\
\text { п/п }\end{array}$} & \multirow{2}{*}{$\begin{array}{l}\text { Наимено- } \\
\text { вание } \\
\text { фактора } \\
\text { (вид работ) }\end{array}$} & \multicolumn{6}{|c|}{$\begin{array}{c}\text { Максимальный уровень воздействия } S_{i} \\
\text { на компоненты природной среды }\end{array}$} & \multirow{2}{*}{$\begin{array}{c}\text { Уровень } \\
\text { комфорт- } \\
\text { ности } \\
S\end{array}$} & \multirow{2}{*}{$\begin{array}{c}\text { Града- } \\
\text { ция }\end{array}$} & \multirow{2}{*}{$\begin{array}{c}\text { Оценка } \\
\text { комфортности } \\
\text { условий жизне- } \\
\text { деятельности }\end{array}$} \\
\hline & & $\begin{array}{c}\text { Снеговые } \\
\text { отлож. }\end{array}$ & $\begin{array}{c}\text { Дон- } \\
\text { ные } \\
\text { отлож. } \\
\end{array}$ & $\begin{array}{l}\text { Пов. } \\
\text { воды }\end{array}$ & $\begin{array}{l}\text { Почв. } \\
\text { отлож. }\end{array}$ & $\begin{array}{l}\text { Раститель- } \\
\text { ность }\end{array}$ & $\begin{array}{c}\text { Степень } \\
\text { деграда- } \\
\text { ции почв } \\
\end{array}$ & & & \\
\hline 1 & $\begin{array}{c}\text { Поиско- } \\
\text { вые }\end{array}$ & 1,3 & 1,2 & 0,6 & 1,1 & 0 & 2 & 6,2 & II & $\begin{array}{c}\text { Условно } \\
\text { комфортные }\end{array}$ \\
\hline 2 & $\begin{array}{l}\text { Разведоч- } \\
\text { ные }\end{array}$ & 3,8 & 3 & 0,9 & 1,5 & 0,4 & 4 & 13,7 & IV & $\begin{array}{c}\text { Весьма } \\
\text { некомфортные }\end{array}$ \\
\hline 3 & Добычные & 4 & 3,4 & 2,3 & 1,6 & 0,6 & 4 & 15,6 & IV & $\begin{array}{c}\text { Весьма } \\
\text { некомфортные }\end{array}$ \\
\hline 4 & $\begin{array}{l}\text { Перераба- } \\
\text { тывающие }\end{array}$ & 4 & 3,4 & 2,3 & 1,6 & 0,6 & 4 & 15,6 & IV & $\begin{array}{c}\text { Весьма } \\
\text { некомфортные }\end{array}$ \\
\hline
\end{tabular}

Оиенка комфортности жизнедеятельности в Айхальском ГПК 


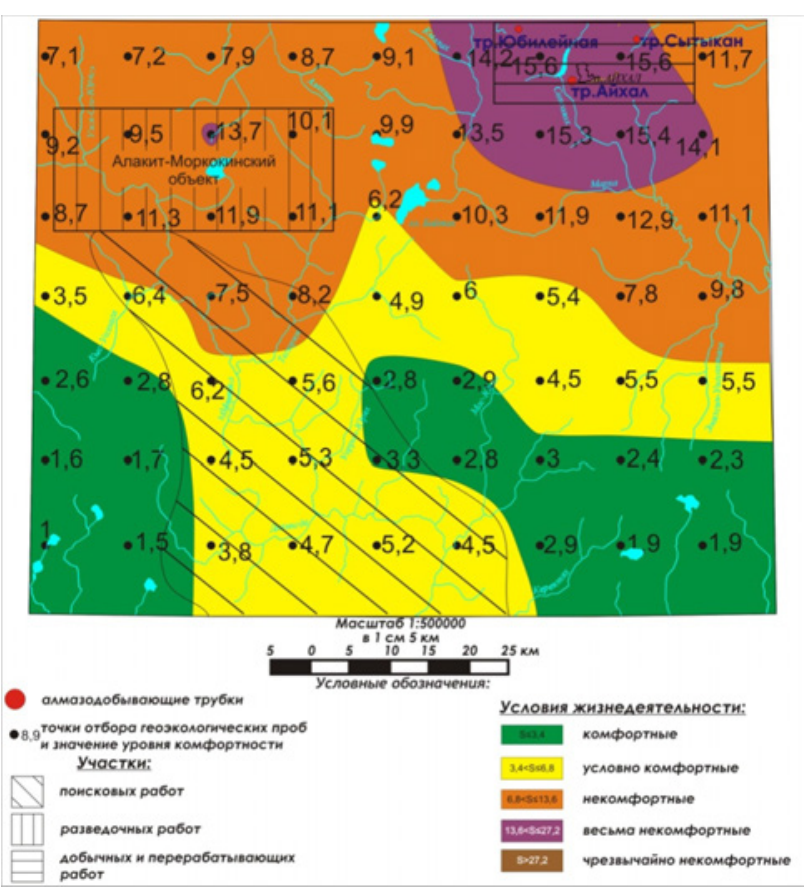

Puc. 5. Карта оценки комфортности жизнедеятельности на территории Айхальского горнопромышленного комплекса.

жизнедеятельности, занимает около $10 \%$ территории и расположена в северо-восточной и северо-западной частях Айхальского ГПК. Она вытянута на юговосток, что объясняется северо-западным направлением ветра в данном районе.

Негативное воздействие добычных работ выражено в виде нарушения сплошности и монолитности криолитозоны при разработке карьера; изъятия из природных ГЭС значительных площадей под отвалы горнодобывающей деятельности с соответствующим уничтожением на них почвенного и растительного покровов; ветровой и водной транспортировки меди, никеля, свинца, цинка, лития на прилегающие к отвалам участки геоэкологической системы; загрязнения атмосферы организованными выбросами.

Переработка полезных ископаемых также формирует весьма некомфортные условия жизнедеятельности. Это проявлено в виде нарушения сплошности и монолитности криолитозоны в результате строительства и эксплуатации перерабатывающего комплекса; развития криогенных процессов в местах строительства инженерных и транспортных сооружений: термокарст, наледи, морозное пучение и т.п.; загрязнения поверхностных и подземных вод сточными водами предприятия.

Разведочные работы формируют весьма некомфортные и некомфортные условия жизнедеятельности, что проявляется в виде нарушения сплошности и монолитности криолитозоны; неорганизованных выбросов в атмосферу пыли и газов; механического нарушения почвенного и растительного покрова; замусоривания территории неликвидированными буровыми, промышленными, твердыми бытовыми отходами; отсутствия рекультивации площадок буровых работ после окончания разведочной деятельности.

В местах проведения поисковых работ фиксируются зоны с условно комфортными условиями жизнедеятельности. Данная зона занимает около 15-20\% изучаемого района и приурочена к южной части Айхальского ГПК.

Негативное воздействие поисковых работ на компоненты природной среды фиксируется на стадии геологической съёмки, где происходит нарушение, в основном, почвенно-растительного слоя [6].

Комфортные условия жизнедеятельности фиксируются, в основном, в юго-восточной и юго-западной частях Айхальского ГПК, что объясняется отсутствием техногенного воздействия на компоненты природной среды. Данная зона занимает 20-25 \% изучаемого района. На ее территории преобладают природные факторы формирования геоэкологических условий, что подтверждается допустимым состоянием всех компонентов ГЭС.

Таким образом, можно сделать вывод, что максимальный дискомфорт создают не только добычные и перерабатывающие, но также и разведочные работы. Зона с весьма некомфортными условиями жизнедеятельности приурочена к местоположению алмазосодержащих трубок Айхал, Сытыкан и Юбилейная. В районе проведения разведочных работ на АлакитМоркокинском объекте формируются зоны весьма некомфортных и некомфортных условий жизнедеятельности. Минимальное воздействие на все компоненты природной среды оказывают поисковые работы, в районе проведения которых фиксируются условно комфортные условия жизнедеятельности. Территории, на которых отсутствуют какие-либо виды техногенного воздействия на природную ГЭС, были оценены как комфортные.

\section{ЛИТЕРАТУРА}

1. Аржанова, В. С. Трансформация почв под влиянием горнопромышленного типа техногенеза / В. С. Аржанова, В. П. Елпатьевская, П. В. Елпатьевский // Современные проблемы загрязнения почв. Сб. мат-лов II Межд. научн. конф. - М., 2007. - С. 55-59.

2. Иванов, В. В. Отчет о результатах поисков коренных месторождений алмазов на Алакит-Моркокинском междуречье. / В. В. Иванов, Е. Н. Иванюшина. - Айхал, 2005. - 268 с.

3. Косинова, И. И. Методы эколого-геохимических, эколого-геофизических исследований и рациональное недропользование. / И. И. Косинова, В. А. Богословский, В. А. Бударина. - Воронеж, 2004. - 281с.

4. Трансформация экологических функций литосферы в эпоху техногенеза: Уч. пособие / В. Т. Трофимов [и др.]. М.: Изд-во «Ноосфера», 2006. - 720 с.

5. Мильков, Ф. Н. Физико-географическое и эколого-географическое районирование. Их соотношение / Ф. Н. Мильков // Эколого-географические районы Воронежской области. - Воронеж, 1996. - С. 47-48.

6. Хованская, М. А. Эколого-геохимическая оценка территории поисковых и геологоразведочных работ на АлакитМоркокинском объекте (Саха-Якутия). / М. А. Хованская, И.И. Косинова // // Вестн. Воронеж. гос. ун-та. Сер.: Геология. -2011 . - № 1. - С. 275-280 . 
7. Хованская, М. А. Методика оценки комфортности жизнедеятельности в горнодобывающих районах. / М.А. Хованская, И. И. Косинова // Известия высших учебных заведений. Геология и разведка. Издательство: Российский государственный геологоразведочный университет им. С. Орджоникидзе (Москва). - 2014 - №6 - 54-58.

Воронежский государственный университет

Хованская Мария Александровна, дочент, кандидат географических наук

E-mail: mashunia86@yandex.ru

Тел.: 8-(473)-2208-289; 8-952-547-70-66

Косинова Ирина Ивановна, доктор геолого-

минералогических наук, профессор, заведующая кафедрой экологической геологии

Тел.: 8-(473)-2208-289; 8-920-457-457-1

e-mail: kosinova777@ya.ru

Воробьёва Мария Геннадьевна, кандидат геологоминералогических наук, доиент кафедры экологической геологии

E-mail:mzaridze@mail.ru

Тел: 8-(473)-2208-289; 8-903-858-12-88
8. Методика определения размеров ущерба от деградации почв и земель. Утверждена Минприроды России и Роскомземом от 29 июля 1994 г. № 3-14-2/1139. Комитет РФ по земельным ресурсам и землеустройству.

Voronezh State University

Khovanskaia M. A., PhD in Geography, Assistant professor of Ecological Geology Department

E-mail: mashunia86@yandex.ru

Tel.: 8-(473)-2208-289; 8-952-547-70-66

Kosinova I. I., Doctor of Geological and Mineralogical Sciences, professor, the Head of Ecological Geology Department

E-mail: kosinova777@ya.ru

Tel.: 8-(473)-2208-289; 8-920-457-457-1

Vorobyeva M. V., candidate of Geological and Mineralogical Science, Assistant professor of Ecological Geology Department E-mail: mzaridze@mail.ru

Tel: 8-(473)-2208-289; 8-903-858-12-88 